\title{
Diskursiivisesti muotoutunut maa
}

\author{
Karonen, Petri ja Antti Räihä (toim.). 2014. Kansallisten instituutioiden \\ muotoutuminen: Suomalainen historiakuva Oma Maa-kirjasarjassa 1900- \\ 1960. Helsinki: SKS. 457 sivua.
}

Heidi Haapoja-Mäkelä

$\mathrm{O}$ ma Maa -kirjasarja oli ilmestyessään aikansa Wikipedia: vuosina 1906-1962 ilmestynyt tietoteos kuului usean suomalaisen kodin irtaimistoon. Aikansa ansioituneiden tutkijoiden ja vaikuttajien kirjoitukset oli suunnattu "kansalle", siis eliitin lisäksi myös alemmille yhteiskuntaluokille. Kansallisten instituutioiden muotoutuminen: Suomalainen historiakuva Oma Maa-kirjasarjassa 1900-1960 -teos on historiantutkijoiden koitos jäsennellä kirjasarjan ainutlaatuista aineistoa, joka tarjoaa hienon pysäytyskuvan historiantutkimuksen historiasta ja historiapolitiikan muotoutumisesta.

Teoksessa on päätetty käsitellä instituutioiden historiaa, vaikka Oma Maa -kirjasarja tarjoaisi mahdollisuuden tutkia valtavasti erilaisia aiheita. Instituutioiden historiaan keskittyminen on kuitenkin ansioitunut valinta, sillä tämän avulla tutkijat ovat päässeet käsiksi merkityksellisiin kansakunnan rakennusaineisiin. Käsiteltyjä institutionaalisia rakenteita ovat muun muassa valtio, kirkko, kansa, valtaorganisaatiot, lait, sosiaaliturva, koulujärjestelmä ja tiedonvälitys. Teos jakautuu kolmeen osaan, joista ensimmäisessä käsitellään valtion, uskonnon ja kansan käsitteitä, toisessa valtaorganisaatioiden rakentamista ja kolmannessa vuorovaikutusta, tietoisuutta ja konflikteja.

\section{Nykyisyyttä historiallisten lähteiden avulla valaiseva menetelmä}

Artikkelikokoelman aineisto on valtava. Tästä huolimatta teoksen sisäinen koherenssi on varsin linjakas, toisin kuin monesti artikkelikokoelmien kohdalla käy; koska kaikilla kirjoittajilla on ollut edessään sama aineisto, artikkelit resonoivat harvinaisen hyvin toistensa kanssa. Tämä teos ei ole sekalainen otos hiukan toisiinsa liittyviä kirjoituksia, vaan selvästi harkittu ja tarkkaan suunniteltu kokonaisuus. Tämä ote tulee esille myös kirjan johdannossa, jossa valotetaan lyhyesti teoksen syntyprosessia: "Kirjoittajat ovat yhteisissä kokoontumisissaan rajanneet kirjan sisällön nyt käsillä oleviin teemoihin, jotka ovat nousseet tutkimusaineistojen läpikäynnin ja pitkällisten pohdintojen jälkeen kaikkein keskeisimmiksi" (s. 26). Pitkälliset pohdinnat voi todella aistia kirjaa lehteillessä. 
Folkloristille historiantutkimus erottuu usein melko omanlaisenaan tieteenalana: teksteissä ei viittailla ranskalaisiin filosofeihin, tunnettuihin kieli- tai yhteiskuntatieteilijöihin tai antropologian klassikoihin, eivätkä teoreettiset keskustelut välttämättä resonoi juuri lainkaan perinteentutkimuksen nykyisten paradigmojen kanssa. Tästä huolimatta historiantutkijoiden tapa lukea lähteitään ja kontekstualisoida aineistonsa ajankuvaan on usein hämmästyttävän tarkkanäköinen ja ulkoa käsin tarkasteltuna vaikuttava. Tässäkin teoksessa lähteitä on luettu tarkkaan, ja aineisto myös keskustelee nykypäivän kanssa. Teos selittää ja avaa sitä, miksi ja miten suomalaisuus ja Suomen historia ymmärretään nykyisyydessä. Oman Maan merkitys ei ole ollut historiakuvan muotoutumisen prosesseissa ollenkaan vähäinen. Kuten esimerkiksi Ulla Koskinen ja Piia Einonen toteavat "Hallinnon sankarilliset yksilöt ja kasvoton koneisto" -artikkelissaan, Oma Maa on osaltaan osallistunut esimerkiksi suomalaisen suurmieshistorian luomiseen: "Oman Maan arviot hallitsijoiden merkityksestä ovat jääneet pysyvästi osaksi suomalaista historiaperintöä. Esimerkiksi yhä vielä tunnetuimmat Ruotsin kuninkaat lienevät Kustaa Vaasa ja Kustaa II Aadolf, joiden mainetta eniten ylistellään Oman Maan artikkeleissa. Uudelleen virinnyt tutkimuksellinen kiinnostus henkilöhistoriaan, tällä kertaa kriittisen biografisen tutkimuksen muodossa, on tiputellut suurmiehiä jalustoiltaan mutta ei ole voinut juuri muuttaa Oman Maan mukaista kansallista suurmiesgalleriaa." (S. 128.)

Historiantutkimuksen tavassa sanoittaa tutkimuksen menetelmiä on usein jotakin ehkä kauniiksikin kuvailtavaa suoraviivaisuutta. Menetelmiä ei pyritä pukemaan "kriittiseksi diskurssianalyysiksi" tai muuksi muodikkaaksi, vaan, kuten tässäkin teoksessa, menetelmäksi mainitaan yksiselitteisesti "tekstien lähiluku". Tämän teoksen kohdalla lukijalle jää hieman hämäräksi, mitä lähiluku loppujen lopuksi tarkoittaa, mutta kirjoittajille tämä vaikuttaa olevan selvää, sillä kompastelua ei teksteissä juuri näy. Johdannossa mainitaan suhteellisen suurpiirteisesti, että "lähestymistapa mahdollistaa aineistojen syvällisen analysoinnin, kerrontarakenteiden avaamisen sekä eri kanteilta tulkittujen aineistojen vivahteiden esiin nostamisen" (s. 26).

Aineistojen syvällinen analysointi johtaa siihen, että tutkijat ovat onnistuneet eivät vain kuvailemaan Oman Maan tekstejä, vaan myös tulkitsemaan niitä herkällä korvalla siten, että lukijalle näyttäytyy hyvin konkreettisesti se, miten valtion ja kansakunnan konstruktioita on diskursiivisesti luotu ja erityisesti levitetty laajemman yleisön tietoisuuteen.

\section{Pureskeltavaa perinteentutkijoille}

Osa teoksen artikkeleista on aineistoltaan ja tyyliltäänkin hieman puisevaa. Tämä on toki henkilökohtainen intressikysymys: oman tutkimukseni kannalta sotiin ja lainsäädäntöön liittyvät artikkelit eivät tunnu erityisen relevanteilta. Joku toinen voi eittämättä saada näistä paljonkin, myös folkloristiikan tai muun lähialan tutkimuksen puitteissa. Sen sijaan esimerkiksi valtion syntyä, kirkon ja kansan suhteen rakentumista, perheinstituution muotoutumista, koulutusjärjestelmän ja hyvinvointiyhteiskuntadiskurssien muovautumista käsittelevät artikkelit resonoivat paljonkin perinteentutkimuksen klassisten tutkimusintressien kanssa; näistä voi saada hyvinkin paljon irti, jos käsittelee esimerkiksi kansan käsitteen ideologista rakentumista tai institutionaalisen ja vernakulaarin historiallista vuorovaikutusta.

Esimerkiksi ne, joita kiinnostavat sukupuoleen liittyvät kysymykset erityisesti historiallisissa konteksteissa, saattavat olla inspiroituneita lukemaan Jari Eilolan ja Heli Valtosen artikkelia "Perheen säätely modernisoituvassa Suomessa". Artikkelissa käsitellään sitä, miten Omassa 
Maassa määriteltiin perhettä ja toisaalta siihen liittyviä käsitteitä kuten naista, miestä ja yhteiskuntaluokkaa. Artikkeli osoittaa hyvin sen, miten näiden määrittelyjä muokkasi voimakkaasti sivistyneistö ja sen identiteetin rakentamiseen liittyvät tavoitteet. Nämä tavoitteet ja sivistyneistön ideaalikuva kansasta ja perheyhteisöstä värittivät toki myös esimerkiksi perinteen keruutyötä ja sen tulkintoja ja lopputuloksia noin sata vuotta sitten.

Myös niin sanottua modernisaatiota ja sen vaikutuksia käsityksiin perinteistä tutkivien intresseissä saattaa olla tutustuminen kirjan artikkeleihin, sillä niiden pitkä aikajänne 1900-luvun alusta 1960-luvulle tarjoaa laajan näkökulman aiheeseen yhteiskunnallisen kontekstualisoinnin kannalta. Varsin kiinnostava aihe on esimerkiksi kansanvalistuksen, työväenaatteen ja hyvinvointiyhteiskuntadiskurssien rajapinnat ja vuorovaikutukset kansanomaisen ilmaisun kanssa. Näitä on jonkin verran tutkittukin (vrt. esimerkiksi Kurkela 1989; Mikkola 2009; Salmi-Niklander 2004; Stark 2011), mutta alue tarjoaisi runsaasti pinta-alaa uudelle tutkimukselle. Tällaisen tutkimuksen taustoittamiseen oivia olisivat esimerkiksi Minna Harjulan artikkeli "Terveys ja sosiaaliturva kansakunnan rakentajia", Antero Holmilan, Ulla Koskisen, Nils Erik Villstrandin ja Petri Karosen "Tiedonvälitys sivistysmissiosta uutisiin" sekä Mervi Kaarnisen "Suomen kansa opin tiellä".

\section{Lopuksi}

Käsillä oleva artikkelikokoelma on kiinnostava avaus suomalaiseen historiakuvaan. "Suomen historia" on konstruktiona varsin nuori, mutta yhtäaikaisesti jo tarpeeksi vanha, jotta voidaan tarkastella varsin pitkiä muutoslinjoja sen tutkimisen ja esittämisen paradigmoissa. Kuten kirjan johdannossa todetaan, viime aikoina historian käyttämistä osana kansallisvaltioiden rakentamista on tutkittu suhteellisen paljon. Tähän on myös enenevässä määrin alettu kiinnittää huomiota, mikä saattaa radikaalistikin poiketa niin sanotusti "tavallisten ihmisten" näkemyksistä kansallisuudesta ja siihen liittyvästä historiatietoisuudesta (vrt. Torsti 2012).

Kansallisten instituutioiden muotoutuminen -teos osallistuu näihin kansallisvaltion rakentamiseen ja historian käyttämiseen liittyviin keskusteluihin. Sen näkökulma on historiapoliittinen: teoksen sivuilla pääsee hyvin mukaan siihen, miten historiaa ja menneisyyttä on eri aikoina muistettu ja tulkittu. Oma Maa -kirjasarjan avulla pääsee käsiksi esimerkiksi siihen, miten suomalaisten menneisyystulkinnan pääpaino on siirtynyt vuoden 1809 tapahtumista kohti toisen maailmansodan aikaa. Suomen historiasta ja sen tulkinnoista ei enää voitane puhua ilman talvi- ja jatkosotaa. Kuten kirjoittajat huomioivat (s. 15), menneisyystulkinnat ovat kuitenkin aina myös unohtamista ja valikointia, siis erilaisia hiljaisuuksia koskien vaikkapa yhteiskuntaluokkia, ihmisryhmiä, alueellisuuksia tai etnisyyksiä. Kansallisten instituutioiden muotoutuminen -teos vastaa osaltaan näihin hiljaisuuksiin: kirjoittajat tuovat esille myös sitä, miksi jokin tai joku jäi Oma Maa -teoksessa huomioitta. 


\section{Kirjallisuus}

Kurkela, Vesa. 1989. Musiikkifolklorismi ja järjestökulttuuri: Kansanmusiikin ideologinen ja taiteellinen hyödyntäminen suomalaisissa musiikki- ja nuorisojärjestöissä. Jyväskylä: Gummerus.

Mikkola, Kati. 2009. Tulevaisuutta vastaan: Uutuuksien vastustus, kansantiedon keruu ja kansakunnan rakentaminen. Helsinki: Suomalaisen Kirjallisuuden Seura.

Salmi-Niklander, Kirsti. 2004. Itsekasvatusta ja kapinaa: Tutkimus Karkkilan työläisnuorten kirjoittavasta keskusteluyhteisöstä 1910- ja 1920-luvuilla. Helsinki: Suomalaisen Kirjallisuuden Seura.

Stark, Eija. 2011. Köyhyyden perintö: Tutkimus kulttuurisen tiedon sisällöistä ja jatkuvuuksista suomalaisissa elämäkerta-ja sananlaskuaineistoissa. Helsinki:Suomalaisen Kirjallisuuden Seura.

Torsti, Pilvi. 2012. Suomalaiset ja historia. Tampere: Gaudeamus.

Filosofian tohtori, musiikin maisteri Heidi Haapoja-Mäkelä toimii post doc -tutkijana Helsingin yliopistossa Koneen säätiön rahoittamassa "Omistajuus, kieli, kulttuuriperintö: Kansanrunousideologiat Suomen, Karjalan tasavallan ja Viron alueilla" -projektissa. 